\title{
VIDAS SECAS DE DIREITOS: DESCONSTRUÇÃO E ALTERIDADE COMO POSSIBILIDADES PARA O RECONHECIMENTO
}

\author{
Carolina Ribeiro Santana*
}

\begin{abstract}
RESUMO
O presente artigo trata da interface entre o direito e a literatura e as possibilidades que surgem a partir dessa relação. Um olhar por meio da literatura deixa transparecer um direito que necessita ser revisto em suas certezas e questionado em suas positivações. O romance regionalista "Vidas Secas", de Graciliano Ramos, é a obra da qual partimos a fim de realizar reflexões acerca da dogmática. O campo "direito e literatura" aproximou-se, nestes estudos, da filosofia do direito devido ao tema abordado, uma vez que pensar os sujeitos por meio da literatura levou ao questionamento acerca da temática do "eu" e do "outro" e de como esse "outro" é visto pelo direito contemporâneo. As teorizações de Emmanuel Levinas e Jacques Derrida sustentam as análises realizadas em busca de uma desconstrução do direito posto em busca de um direito que possa experimentar a justiça e aproximar-se da realidade social que nos cerca.
\end{abstract}

Palavras-chave: interdisciplinaridade; literatura; alteridade; reconhecimento.

SUMÁRIO: 1 O DIREITO E A LITERATURA: INTERFACES NECESSÁRIAS; 2 AS DUAS CELAS: A SECA E A CERCA; 3 DESCONSTRUÇÃO E DIREITO: DO EU AO OUTRO; 4 CONSIDERAÇÕES FINAIS; 5 REFERÊNCIAS.

\section{O DIREITO E A LITERATURA: INTERFACES NECESSÁRIAS}

Na planície avermelhada os juazeiros alargavam duas manchas verdes. Os infelizes tinham

${ }^{*}$ Graduanda em Direito pela UFPR e bolsista do CNPq. Linha: Perspectivas da dogmática Crítica. Email: santanakk@yahoo.com.br 


\section{VIDAS SECAS DE DIREITOS: DESCONSTRUÇÃO E ALTERIDADE COMO POSSIBILIDADES PARA O \\ RECONHECIMENTO}

caminhado o dia inteiro, estavam cansados e famintos. Ordinariamente andavam pouco, mas como haviam repousado bastante na areia do rio seco, a viagem progredira bem três léguas. Fazia horas que procuravam uma sombra. A folhagem dos juazeiros apareceu longe, através dos galhos pelados da caatinga rala.

Arrastaram-se para lá, devagar, sinhá Vitória com o filho mais novo escanchado no quarto e o baú de folha na cabeça, Fabiano sombrio, cambaio, o aió a tiracolo, a cuia pendurada numa correia presa no cinturão, a espingarda de pederneira no ombro. O menino mais velho e a cachorra Baleia iam atrás.

Assim começa o romance Vidas Secas, de Graciliano Ramos, publicado em 1938. Uma família de retirantes que foge da seca em busca de um lugar com emprego, ou com terra para se plantar.

O que esse romance tem a ver com o Direito? O Direito e a Literatura estabelecem relações interessantes para a área jurídica?

As ciências buscam, cada vez mais, a interdisciplinaridade a fim de que os campos do conhecimento não se tornem ilhas isoladas, pontos insulares de saber. Portanto, a interface entre o direito e a literatura se faz necessária na medida em que ambos são reflexos da cultura de um povo, passíveis de se complementar e de evidenciar que a literatura expressa a vivência de uma determinada sociedade e que, ainda que no campo mais longínquo da ficção, guarda relações íntimas com a realidade de onde nascem as leis e suas ficções jurídicas. ${ }^{1}$

Direito e Literatura é um novo espaço interdisciplinar para refletir acerca de questões como o que é o Direito, quem deve obedecê-lo e por que ou ainda, o que é a Justiça, o que a diferencia do sentimento de vingança etc. Por ser um campo de estudo interdisciplinar os nomes associados a essa área encontram-se em diversos campos acadêmicos, podemos citar Jacques Derrida, Martha Nussbaum, François Ost e Stanley

${ }^{1} \mathrm{O}$ direito produz pessoas, a literatura, personagens. As pessoas criadas pelo direito são, segundo François Ost, exemplos que servem de referência para o comportamento padrão. Há o "bom pai de família", o usuário prudente", "o concorrente leal", o "profissional diligente", poderíamos citar ainda, a "mulher honesta", o "homem médio", entre tantos outras ficções jurídicas criadas para normatizar a vida em coletividade. As personagens literárias, em evidente diferenciação, são ambíguas, ora verdadeiras, ora mentirosas, não são destinadas a servir de exemplo. Para as personagens da literatura nada é impossível, talvez, assim como na vida. Ch. Biet. Droit et littérature sous L'Ancien Régime. Le jeu de la valeur et de la loi. Paris, Honoré Champion, 2002, p. 98. (Apud OST, François. Contar a lei: as fontes do imaginário jurídico. São Leopoldo: Unisinos, 2004, p. 16). 
Fish $^{2}$.

\author{
Conforme Vera Karam de Chueiri:
}

Direito e Literatura podem dizer respeito tanto ao estudo de temas jurídicos na Literatura, e neste caso estar-se-ia referindo ao Direito na Literatura; como à utilização de práticas da crítica literária para compreender e avaliar o Direito, as instituições jurídicas, os procedimentos jurisdicionais e a justiça, e neste caso, estar-se-ia referindo ao Direito como Literatura. No primeiro caso, é o conteúdo da obra literária que interessa ao Direito, enquanto, no segundo, a própria forma narrativa da obra pode servir para melhor compreender a narrativa jurídica, como, por exemplo, as sentenças que os juízes constroem. ${ }^{3}$

A experiência literária questiona e ao questionar perturba a autoridade e a pertinência da questão acerca da essência, qual seja, aquela que pergunta “o que é..?”. Essa maneira perturbadora com a qual a literatura atravessa a linguagem da verdade é de extrema importância para o direito e para a Justiça ${ }^{4}$.

A busca da verdade, tão cara à instrumentalização do direito, é posta em questão pela literatura e, nesse sentido, é que se torna interessante essa interdisciplinaridade. François Ost afirma que a literatura jamais se reduzirá a demonstração de uma tese, a valorização de incertezas, das ambivalências e dos paradoxos que afetam toda a realidade por menos complexa que seja, como o são necessariamente as coisas humanas - ambivalências e paradoxos que a ciência jurídica é às vezes levada a reduzir e a simplificar. ${ }^{5}$

Há, em Vidas Secas, uma atmosfera de imobilidade que reflete a escolha do escritor em privilegiar o que se passa na alma das personagens. São seres ensimesmados, semimudos, fechados na ignorância e no analfabetismo, mas que mesmo assim precisam se comunicar com o mundo, vivem em uma conflituosa busca por algo que os torne semelhantes aos demais sujeitos, os sujeitos da cidade, os

${ }^{2}$ CHUEIRI, Vera Karam de. Direito e literatura. In. BARRETO, Vicente de Paulo. Dicionário de filosofia do direito. Rio de Janeiro/São Leopoldo: Renovar/Unisinos, 2006. p. 234.

${ }^{3}$ Ibidem, loc. cit.

${ }^{4}$ Ibidem, loc. cit.

${ }^{5}$ OST, op. cit., p. 386. 
sujeitos de que falam as leis.

A injustiça social atravessa como grito a cortina de silêncio das páginas desse romance de realismo crítico, faz-se a voz dos personagens emudecidos. São personagens acostumados à incomunicabilidade dos bichos (como se desgraças grandes ou dores fortes demais não encontrassem expressão possível na linguagem humana). ${ }^{6}$

Mas é preciso a linguagem humana para que se perceba o sofrimento? A dor e a injustiça já estão no rosto, ainda que não se empregue a palavra, é o que nos falará Emmanuel Levinas, filósofo lituano, naturalizado francês. É necessário vivenciar a fusão entre a exterioridade e a interioridade, do outro com o eu que o contempla.

O capítulo Cadeia, do romance de Graciliano Ramos, possibilita uma análise nesse sentido.

\section{AS DUAS CELAS: A SECA E A CERCA}

"Fabiano tinha ido à feira da cidade comprar mantimentos. Precisava sal, farinha, feijão e rapadura." Por considerar-se um bruto sentia-se pouco a vontade na cidade, procurava palavras difíceis na esperança de que o respeitassem.

Nesse dia em que foi à cidade um "soldado amarelo" chamou Fabiano para jogar trinta-e-um; e Fabiano, por respeito e medo da farda, aceitou. "Fabiano caminhou atrás do amarelo que era autoridade e mandava. Fabiano sempre tinha obedecido.” Ao sentar-se na esteira, para jogar, Fabiano lembrou-se de Sinhá Vitória e de como ela iria ficar danada ao saber que ele gastara dinheiro com jogo, "ergueu-se furioso, saiu da sala, trombudo”.

Essa atitude tornou-se motivo suficiente para que o soldado amarelo se

\footnotetext{
${ }^{6}$ FELINTO, Marilene. In:_____Posfácio à 97 edição de Vidas Secas. p. 134-135.
} 
sentisse desrespeitado e, após uma surra de facão, prendesse o pai da família de retirantes. "Fabiano marchou desorientado, entrou na cadeia, ouviu sem compreender uma acusação medonha e não se defendeu”. Permaneceu calado quando o que mais queria era falar, era saber falar. Não entendia porque o soldado amarelo tinha feito aquilo.

Percebeu que o que acontecera não tinha justificativa, nem explicação. $O$ soldado amarelo, com sua farda e seu facão, fez prevalecer sua "autoridade", uma autoridade que nada tinha a ver com o direito, mas tão-somente com a força e com o medo.

Emmanuel Levinas explica a autoridade do amarelo como algo proveniente da lógica do pensamento Ocidental, que coloca o eu como sujeito absoluto dando origem a uma ação que ignora o olhar do outro, o apelo do outro e, também, uma necessária, contínua e cada vez mais profunda interpretação do rosto do outro. ${ }^{7}$

Fabiano sabia, porém, que era fácil colocar um cabra como ele na cadeia, não entendia se havia sido por engano ou por vaidade do amarelo, sabia somente que para os brutos as coisas eram assim, “acostumara-se a todas as violências, a todas as injustiças”.

Ouvira na cadeia: "apanhar do governo não é desfeita”. E entendia menos ainda, não se convencia de que o soldado amarelo fosse governo. Fabiano pensava: "Governo, coisa distante e perfeita não podia errar. O soldado amarelo estava ali perto, além da grade, era fraco e ruim, jogava na esteira com os matutos e provocavaos depois. O governo não podia consentir tão grande safadeza”. Fabiano idealizava o governo, possuía a idéia de que a instituição servia para protegê-lo, formada por homens muito diferentes dele e do amarelo; homens distintos, úteis e com presteza no linguajar.

Fabiano acreditava em um governo perfeito e temia a farda do soldado amarelo. Cria na possibilidade de existência de um direito que o respeitasse, mas temia

\footnotetext{
${ }^{7}$ LEVINAS, Emmanuel. Liberté et commandement. In: ; PEPERZAK, A. Ética prima come filosofia. Milão: Guerini e Associados, 1993, p. 22.
} 


\section{VIDAS SECAS DE DIREITOS: DESCONSTRUÇÃO E ALTERIDADE COMO POSSIBILIDADES PARA O RECONHECIMENTO}

o poder que usava da força para se afirmar.

A diferença era que o amarelo, além de impor autoridade com sua força, vivia na cidade, sabia se expressar. Mesmo percebendo que o soldado amarelo não era Governo, Fabiano temia-o, pois temia a força das palavras, que tão pouco sabia usar.

A cidade representava um mundo no qual o poder (o acesso a ele ou a tomada dele para si) era regido pela palavra, percebia de imediato a sua impotência, pois, na cidade, Fabiano estava sempre cercado por silêncios opressores e palavras longas e difíceis.

Fabiano pensava: "Sempre que os homens sabidos lhe diziam palavras dificeis ele saía logrado. Sobressaltava-se escutando-as. Evidentemente só serviam para encobrir ladroeiras. Mas eram bonitas [...] Se lhe dessem um tempo, contaria o que se passara. Era bruto sim senhor, nunca havia aprendido, não sabia explicar-se. Estava preso por isso? Como era? Então mete-se um homem na cadeia porque ele não sabe falar direito? Que mal fazia a brutalidade dele? Vivia trabalhando como um escravo. [...] Tinha culpa de ser bruto? Quem tinha culpa?”

Fabiano intuía que somente o domínio de uma linguagem poderia levá-lo a compreender a natureza hostil e a enfrentar de modo menos desigual os falantes da cidade como o soldado que o oprime, explora e humilha. Tinha, diante de si, o desafio de decifrar os códigos e dominar o universo dos signos que transformavam o outro em um poderoso ser de linguagem. ${ }^{8}$

À medida que as horas passavam, Fabiano, na cadeia, começou a convencer-se de que nem ele, nem ninguém que ali se encontrava, prestava para alguma coisa. Precisava de razões para entender por que fora preso daquela maneira, restou-lhe acreditar que eram todos uns inúteis, todos uma lástima, não eram como o doutor juiz de direito, o delegado, o seu vigário e os cobradores da prefeitura. Esses sim mereciam respeito e explicações. Aos brutos nada era preciso explicar.

Fabiano concluiu que assim como ele, seus filhos também eram brutos e que

${ }^{8}$ FELINTO, Marilene. In:_____ Posfácio à 97 _ edição de Vidas Secas. p. 134-135. 
quando crescessem, guardariam as reses de um patrão invisível, seriam pisados, maltratados e machucados por um soldado amarelo. Olhou para si e para os seus e viu que não eram os sujeitos de que falam as leis.

Julgava-se imprestável, sabia que era rude e ignorante, mal sabia falar. Sabia que o Direito, as leis, estavam fora de seu alcance; que sua existência estava fora da esfera de preocupações do governo. Fabiano e sua família viviam excluídos da proteção do Estado, sozinhos, animalizados.

Quantos Fabianos há no país? Quantos filhos de Fabianos condenados a serem brutos? Quantos soldados amarelos usando sua "autoridade"?

Há uma profunda distância entre Fabiano e o soldado amarelo, não existe qualquer vestígio de reconhecimento. Diferente de quando pensa em sinhá Vitória, nos meninos, na cachorra baleia e aí sim se reconhece, só pensa em voltar para casa e deitar na cama de varas que construiu para sinhá. Da mesma forma inexiste qualquer possibilidade de reconhecimento entre Fabiano e o juiz de direito, ou o delegado, por exemplo. Não se vêem como semelhantes ${ }^{9}$.

Contudo nunca iremos reconhecer totalmente o outro em nós, a humanidade é complexa, diversa, culturalmente e economicamente múltipla e, esse aspecto tem servido de justificativa para atrocidades, genocídios e dominações ao longo da história.

Para Emmanuel Levinas o que determina a relação ética é a radical desigualdade do outro em relação ao eu. "A típica retidão de nossa devoção ética ao outro está subsidiada pela radical irretidão que o outro nos apresenta." A distância que separa o eu do outro deve ser o ponto de partida para o respeito, para uma responsabilidade ilimitada para com o outro que excede e precede a liberdade do eu. ${ }^{10}$

A necessidade de uma igualdade material como pressuposto para o respeito só

${ }^{9}$ Aqui não se está a falar do conceito religioso de semelhantes, mas se está a fazer uma referência ao reconhecimento do "outro levinasiano", em que a ética situa-se para além do religioso, das instituições morais teológicas, e caminha próxima a uma razão de religiosidade absoluta, aberta e não institucional, pois para Levinas o pensamento religioso contemporâneo não abrange a realidade social. (LÉVINAS, Emmanuel. Quelques réflexions sur la philosophie du l'hitlérisme. Paris: Payot \& Rivages, 1997, p. 25).

${ }^{10}$ LEVINAS, Emmanuel. Quatre lectures talmudiques. Paris: Minuit, 1968, p. 105. 


\section{VIDAS SECAS DE DIREITOS: DESCONSTRUÇÃO E ALTERIDADE COMO POSSIBILIDADES PARA O RECONHECIMENTO}

tem fomentado o oposto, de vários modos e em vários níveis: barrando o acesso, anulando, descaracterizando, não reconhecendo, desmerecendo, acusando, intimidando, condenando, subjugando. ${ }^{11}$

Em contrapartida, a igualdade formal universal não passa de discurso morto em nosso país de Fabianos e sinhás Vitórias.

Paulo César Duque Estrada aponta um aspecto comum (entre Deleuze, Foucault, Lyotard, Heidegger e Nietzsche) na crítica ao humanismo, "por mais nobre que seja, uma igualdade que reúne todos em um "nós", por exemplo "nós, os humanos", é sempre uma igualdade afirmada, postulada, instituída. Dito de outro modo, ela se estabelece como um ato performático e, nesse sentido, não pode jamais ser entendida como alguma coisa que já existisse por si mesma, em sua presença disponível e comum a todos."12

A professora Katya Kozicki assinala uma direção para lidar com este paradoxo, demonstrando que somente por meio de um compromisso ético com a justiça e o reconhecimento de uma infinita responsabilidade para com o outro será possível administrar a contingência e a diferenciação, típicas deste final século, sem que o reconhecimento das mesmas implique em negligência ética ou indiferença moral. $^{13}$

Todavia, como bem ressalta a professora, não será possível administrar esta contingência se não questionarmos o direito tal como se apresenta. É preciso compreender que grande parte do direito que temos hoje é produto de homens que vivenciavam outro momento histórico, contendo significações e conceitos que não mais dão conta da complexidade da sociedade contemporânea.

E, por ser construção do homem é que o direito pode ser sempre

${ }^{11}$ ESTRADA, Paulo Cesar. Às margens: a propósito de Derrida. São Paulo: Loyola, 2002, p. 46.

${ }^{12}$ Ibidem, loc. cit.

${ }^{13}$ KOZICKI, Katya. A interpretação do direito e a possibilidade de justiça em Jacques Derrida. In: __ Crítica da modernidade: diálogos com o direito. Florianópolis: Boiteux, 2005, p. 131. 
desconstruído. "O fato de que o direito pode ser desconstruído não é uma má notícia. Nós podemos ver nisto uma sorte para a política, para o progresso histórico."14

\section{DESCONSTRUÇÃO E DIREITO: DO EU AO OUTRO}

Ao tratar da instabilidade de que fávamos anteriormente, Jacques Derrida afirma que o caos e a instabilidade não são elimináveis, o mundo se apresenta aos homens "em desordem" e eles necessitam de instrumentos para "ordená-lo". 15 A busca pela justiça pode ser um destes instrumentos.

Não há como esquecer, porém, que sempre haverá tensão, se a sociedade é complexa nem todos hão de concordar com a possibilidade de desconstrução. Fabianos e sinhás Vitórias possuem interesses diferentes de soldados amarelos e patrões invisíveis. Todavia, some-se a isso o fato de que o Direito deve ser sensível às vozes de nossas sinhas Vitórias e nossos Fabianos.

Para Emmanuel Levinas, o apelo por justiça pode ser sentido na experiência com o "outro", com o próximo. A justiça é vista por esse filósofo como o aspecto concreto e formal dessa relação maior com a alteridade absoluta.

Levinas aproxima a ética e a justiça de forma quase indissociável, pois o apelo de justiça está na experimentação, na transcendência da idéia do infinito que é o outro, o que não é senão a ética. Ou seja, a experiência da assimetria significada na epifania ${ }^{16}$

${ }^{14}$ DERRIDA, Jacques. Force de loi: le fondement mystique de l'autorité. Desconstruction and the possibility of Justice. Cardozo Law Review, v. 11, n.5-6, p. 942, july 1990.

15 MOUFFE, Chantal. Desconstruction, pragmatism and the politics of democracy. In: . Desconstruction and pragmatism. London: Routledge, 1997. p. 9.

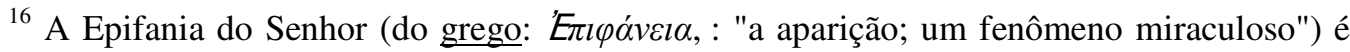

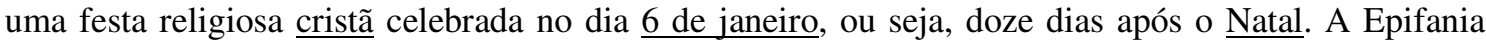
representa a assunção humana de Jesus Cristo, quando o filho do Criador dá-se a conhecer ao Mundo. Na narração bíblica Jesus deu-se a conhecer a diferentes pessoas e em diferentes momentos, porém o mundo cristão celebra como epifanias três eventos: a Epifania propriamente dita perante os magos do oriente (como está relatado em Mateus 2,1-12) e que é celebrada no dia $\underline{6 \text { de janeiro; }}$ a Epifania a João Batista no rio Jordão; e a Epifania a seus discípulos e início de sua vida pública com o milagre de 


\section{VIDAS SECAS DE DIREITOS: DESCONSTRUÇÃO E ALTERIDADE COMO POSSIBILIDADES PARA O RECONHECIMENTO}

da face do outro. Essa experiência "é a relação que se estabelece no infinito espaço assimétrico entre eu e o outro e é estampada na nudez do rosto de quem me convoca a palavra, que me invade violentamente com a demanda da ética e que, por isso, me institui como "eu"",

Levinas afirma que alguém que se exprime na nudez, no rosto, é alguém pronto a apelar ao outro, a se colocar sobre a responsabilidade do outro que, a partir desse momento, responde pelo sujeito que lançou o seu apelo. ${ }^{18} \mathrm{O}$ eu é convocado a tornar-se responsável, surge uma relação com todo o "esplendor e exigência que lhe são próprios"

O apelo por justiça no rosto de Fabiano não pôde ser visto pelo soldado amarelo, não houve a busca pela experiência mesma, da qual fala Levinas, talvez porque a autoridade que reveste o soldado amarelo é suficiente para instituí-lo como “eu”, ou talvez porque Fabiano não se julgou capaz de convocar a palavra.

Porém, a "convocação da palavra" não consiste necessariamente na fala articulada, na fonética, trata-se, na verdade, em dizer o mundo ao outro por meio da visão do rosto. "Ver o rosto é falar do mundo". ${ }^{19}$ Ver o rosto é a transcendência de que fala Levinas, transcendência esta que não se trata de apenas enxergar, mas do primeiro gesto ético.

Levinas pretende com essa idéia resgatar o respeito pelo outro, ou até mesmo a importância da percepção da existência do próximo, tornada sem importância pela cultura Ocidental. A pretensão cognoscitiva da filosofia ocidental reduziu ao eu, gradativamente, qualquer alteridade.

A constante necessidade de dominação de um povo sobre o outro, situação

Caná quando começa o seu ministério. No sentido literário, a "epifania" é um momento privilegiado de revelação, quando acontece um evento ou incidente que "ilumina" a vida da personagem. (Disponível em $<$ http://pt.wikipedia.org/wiki/Epifania $>$. Acesso em 26 maio 2005)

17 HADDOCK-LOBO, Rafael. As muitas faces do outro em Lévinas. In: DERRIDA, Jacques. Desconstrução e ética: ecos de Jacques Derrida. São Paulo: Loyola, 2004. p. 166.

${ }^{18}$ LEVINAS, Emmanuel. Totalité et infini: essai sur l'exteriorité. Paris: Kluver Academic, 1981, p. 73-74.

${ }^{19}$ HADDOCK-LOBO, op. cit., p. 166. 
pela qual constantemente passa a humanidade, intensificada com o advento das guerras colonizadoras, colaborou para um processo de "coisificação" das massas, excluindo a possibilidade de existência de indivíduos, mas tão-somente o geral, o anônimo, o sem rosto.

Sem o respeito pelas individualidades torna-se impossível compreender o olhar do outro em sua plenitude, e compreender o apelo no rosto do outro não significa apreender somente uma singularidade fora de contexto, pelo contrário, no olhar do outro há toda a humanidade. ${ }^{20}$

Segundo Emmanuel Levinas é do reconhecimento e do respeito pelo outro que irá nascer a possibilidade de entendimento entre os indivíduos, o que contribuíra para um entendimento sob a ótica da instituição de uma lei não mais imposta com violência. Neste contexto, ainda, é que podemos falar da liberdade nascida do outro, e não imposta por ele, como fundamento para um direito que garanta o face-a-face, a pluralidade, o encontro entre individualidades. ${ }^{21}$

Para Levinas, o "ver o rosto" significa algo que não se encontra em nenhum sistema referencial de nosso mundo, por isso transcendente, mas que se comparado com a linguagem representa desejo, bondade, justiça.

Essa compreensão de profunda importância para com o outro nada mais é do que uma busca por justiça, através de uma sociedade renovada em seus valores. Uma justiça, porém, que não se confunde com o direito.

A justiça de que fala Levinas nasce da ética, da dimensão mais simples que se possa imaginar, do face-a-face. É o olhar do outro que impede a injustiça, é o olhar do outro que torna o eu responsável por "fazer de tudo para que o outro viva",22

Fabiano, na cadeia, lembrou-se de sinhá Vitória, em como ela deveria estar

${ }^{20}$ LÉVINAS, Emmanuel. Entre nós: ensaios sobre a alteridade. Trad. Pergentino S. Pivatto (coord). Petrópolis: Vozes, 2005, p. 218, 220.

${ }^{21}$ LÉVINAS. Liberté ..., p. 18-21-25.

${ }^{22}$ LÉVINAS, Emmanuel. Transcendência e inteligibilidade. Trad. José F. Colaço. Lisboa: Edições 70, 1991, p. 40. 


\section{VIDAS SECAS DE DIREITOS: DESCONSTRUÇÃO E ALTERIDADE COMO POSSIBILIDADES PARA O RECONHECIMENTO}

desassossegada com a demora dele, pensou em Baleia vigiando a casa e esperando a sua chegada, pensou nos meninos em volta da fogueira... Não há dúvida que, mesmo com os poucos diálogos que travam, mesmo com as comunicações por rosnados e sons guturais, Fabiano e sua família estabelecem relações na eternidade e infinitude, se reconhecem uns nos outros, transcendem em seus rostos, pois, para Levinas, a linguagem está fundada em uma relação anterior à relação de compreensão com os entes, relação esta que seria constituinte da própria razão e que estabelece nossa relação com o outro e na vontade do outro de nos compreender.

Ainda na cadeia Fabiano questionou-se acerca do Governo e da violência por ele empregada. Uma frase não saía de sua cabeça:“-Apanhar do governo não é desfeita'. (...) Enfim apanhar do governo não é desfeita, Por que motivo o governo aproveitava gente assim (como o soldado amarelo)? Só se ele tinha receio de empregar tipos direitos. Aquela cambada só servia para morder as pessoas inofensivas. Ele, Fabiano, seria tão ruim se andasse fardado? Iria pisar os pés dos trabalhadores e dar pancada neles? Não iria."

O trecho final deste fragmento remete ao reconhecimento. Fabiano não pisaria nos pés dos trabalhadores nem lhes daria pancada se andasse fardado, pois Fabiano sabe o que é ser um trabalhador, sabe o que é sentir-se injustiçadamente jogado em uma cela. O reconhecimento, todavia, vai além. Não é preciso "estar na pele" para compreender a necessidade do respeito, o reconhecimento pressupõe o absolutamente outro, um outro infinito, pelo qual sou responsável independentemente de suas características.

Para Levinas esta é a "hora da justiça: quando o amor do próximo e sua proximidade apelam à razão, que se torna bondade, e quando a filosofia transforma-se em sabedoria do amor. Neste momento alguma 'voz profética' relembra aos homens do Estado dos rostos sem face que se escondem por trás das identidades dos cidadãos". 23

Essa é a idéia que faz com que a interdisciplinaridade, a interface entre o

${ }^{23}$ LEVINAS. Entre nós ..., p. 248. 
direito, a filosofia e a literatura ganhe sentido. As relações a partir de então estabelecidas rompem com as facilidades totalitárias da generalidade do humano. As vozes proféticas enunciadas por Levinas significam, provavelmente, a possibilidade de imprevisíveis bondades de que ainda é capaz o Eu. "Elas [as vozes] são audíveis, às vezes, nos gritos que sobem dos interstícios da política e que, independentemente das instâncias oficiais, defendem os direitos do homem; às vezes no canto dos poetas; às vezes, simplesmente na imprensa e nos lugares públicos dos Estados liberais, onde a liberdade e onde a justiça é sempre revisão da justiça e espera de uma justiça melhor." ${ }^{24}$ E por que não dizer que essas vozes também não podem estar na literatura? Elas podem e ali estão presentes a lembrar a existência do outro.

\section{CONSIDERAÇÕES FINAIS}

Esse movimento de retirada das terras secas do direito foi impulsionado pela necessidade de busca de terras mais férteis, não a fim de se abandonar o solo do direito, mas sim na intenção de adubá-lo com a literatura. O solo de onde se parte não oferece mais respostas para a complexidade da sociedade contemporânea, uma vez que nega as identidades, massifica as individualidades e generaliza o humano.

Por meio da interface com a literatura fizemos uma leitura das questões jurídicas com sensibilidades antes não aplicadas, olhares antes não despertados. Direito e literatura estabelecem relações de grande importância uma vez que a literatura provoca, questiona e remexe em estruturas que aparentemente se apresentam como bases bastante sólidas.

Essa nova possibilidade de discurso entre direito e literatura é também considerada pelo filósofo Jacques Derrida que, em suas teorizações, admitia a literatura e a linguagem como constitutivas da sociedade. Dito de outro modo

\footnotetext{
${ }^{24}$ Ibidem, p. 249.
} 


\section{VIDAS SECAS DE DIREITOS: DESCONSTRUÇÃO E ALTERIDADE COMO POSSIBILIDADES PARA O RECONHECIMENTO}

considera-se que a partir do momento que se discute transformação social há que se incluir a temática da linguagem.

A desconstrução, entretanto, não se reduz a um método ou uma análise a ser aplicado, "as propostas de Derrida são um convite à travessia do abismo na corda bamba, sem rede de segurança”. ${ }^{25}$ A desconstrução é um pensamento sempre em processo que desmonta as experiências humanas para compreendê-las, rejeitando dualismos, revirando textos a procura de pressupostos que possam ter permanecido implícitos, sempre em uma incondicionalmente responsável busca por justiça.

Uma vez abordando Jacques Derrida, as relações com Emmanuel Levinas tornaram-se quase que inevitáveis haja vista a influência que este teve na obra daquele. A ética da alteridade e a consideração do outro, propostas por Levinas, são perspectivas excelentes para direcionar um novo olhar sobre o direito ocidental, pósrevoluções burguesas, baseado no individualismo e na razão.

Vidas Secas auxilia neste questionar. Fabiano, sinhá Vitória, o menino mais novo e o menino mais velho travam diversas batalhas mentais para se enxergarem como sujeitos, para se verem como homens capazes de receber respeito e dignidade. Suas elucubrações muitas vezes caem por terra diante de um abuso de autoridade do soldado amarelo, frente à dificuldade de se expressar, ante a negação econômica de ter uma vida decente etc.

Vivemos em um país de retirantes, não apenas os retirantes nordestinos, mas os retirantes de qualquer lugar que partem com o destino em busca de moradia, alimento, emprego e dignidade. Copiamos o direito europeu e americano e fechamos os olhos para os brasis que diariamente se apresentam: explícito na infância a vender balas nos semáforos, obsceno na infância de mini-saia nas esquinas, no pai procurando comida no lixo ${ }^{26}$, na mãe a espera do filho que não mais voltará.

\footnotetext{
${ }^{25}$ MOISÉS, Leyla Perrone. Entre o perigo e a chance. Revista Cult, São Paulo, a. 10, v. 117, p. 46, set. 2007.

${ }^{26}$ Referência ao poema O bicho, de Manuel Bandeira: "Vi ontem um bicho/ Na imundice do pátio/ Catando comida entre os detritos/ Quando achava alguma coisa/ Não examinava nem cheirava: Engolia com voracidade/ O bicho não era um cão, não era um gato, não era um rato./ $\mathrm{O}$ bicho, meu
} 
Cinqüienta milhões de brasileiros vivem abaixo da linha da pobreza ${ }^{27}$, uma grande parte da população do país é analfabeta, a taxa de mortalidade ainda encontrase em altos índices ${ }^{28}$, não há sequer moradia para todos ${ }^{29}$. Ou seja, nossos sujeitos não são todos iguais, não são todos livres, não são todos autônomos.

Essa discrepância, evidenciada também pela literatura, é que deve mover o direito a buscar novas repostas, uma nova ética, uma nova razão. “[...] Nossos contemporâneos, perdidos no mundo globalizado e inebriados pela tecno-ciência (sobretudo aqueles beneficiados pelo apartheid global), não distinguem mais razão e racionalidade, e vão tomando, conforme os interesses técnico-econômicos, as diferentes formas de racionalidade, engendradas pelo dinamismo próprio da razão, como se fossem a própria razão e a esgotassem. E o que é pior: das várias racionalidades contemporâneas, nosso mundo escolheu a mais perniciosa para identificar com a razão, qual seja, a racionalidade programada, tecno-científica, como se a verdade da experiência humana fosse dada pelo número de informações objetivas, matematizáveis, obtidas pelos métodos científicos.” 30

Este artigo apresenta um caminho por meio da sensibilidade literária, da desconstrução e da alteridade. Um caminho, contudo, que não tem um fim, mas que segue as nuances da contingencialidade da sociedade contemporânea. É como faz desconstrução que formula paradoxos irritando e contrariando "aqueles que gostam de respostas claras e categóricas, consideradas racionais, confiáveis e operáveis" 31.

No final de seu comentário feito para o dossiê Derrida, publicado na Revista

Deus, era um homem."

${ }^{27}$ Estudo da FGV-SP, realizado no ano de 2005, revela que 50 milhões de brasileiros são miseráveis, vivem com menos de R\$ 80 por mês. Disponível em: <www.fgv.br>. Acesso em: 12 set. 2007.

${ }^{28}$ A taxa de mortalidade infantil, segundo o último censo, era de 23,6 crianças a cada 1000. Disponível em: <http://portal.saude.gov.br>. Acesso em: 12 set. 2007.

${ }^{29}$ Poema obsceno, de Ferreira Gullar: "Façam a festa/ cantem e dancem/ que eu faço o poema duro/ o poema-murro/ sujo/ como a miséria brasileira."

${ }^{30}$ SAVIAN FILHO, Juvenal. Derrida e a defesa da honra da razão. Revista Cult, São Paulo, a. 10, v. 117, p. 43, set. 2007.

${ }^{31}$ MOISÉS. Entre ..., p. 44. 


\section{VIDAS SECAS DE DIREITOS: DESCONSTRUÇÃO E ALTERIDADE COMO POSSIBILIDADES PARA O RECONHECIMENTO}

Cult, Juvenal Savian Filho aponta uma saída para a reestruturação da ética. Diz ele: “ $A$ saída? Continuar a desconstrução, e ver que uma ética fundamentada apenas na idéia iluminista de dever não é suficiente para atender às necessidades do humano. A partir disso pode-se pensar numa espécie de hiper-ética, aberta às diferentes formas de captar a verdade da experiência humana, como são a fé a crença, a estética etc." 32

O que Savian Filho diz nada mais é que a busca por uma ética que esteja aberta a novos olhares e, eu acrescentaria, que para lidarmos com nossos atuais problemas jurídicos sem resposta é preciso um direito aberto a outros saberes e perspectivas. O direito não é uma ciência autônoma e não encontrará respostas se ficar andando em círculos dentro de seu próprio espaço.

O final do romance narra a família, mais uma vez, se retirando para algum outro lugar, em virtude da seca:

Pouco a pouco uma vida nova, ainda confusa, se foi esboçando. Acomodar-se-iam num sitio pequeno, o que parecia difícil a Fabiano, criado solto no mato. Cultivariam um pedaço de terra. Mudar-se-iam depois para uma cidade, e os meninos freqüentariam escolas, seriam diferentes deles. Sinhá Vitoria esquentava-se. Fabiano ria, tinha desejo de esfregar as mãos agarradas a boca do saco e a coronha da espingarda de pederneira.

Não sentia a espingarda, o saco, as pedras miúdas que lhe entravam nas alpercatas, o cheiro de carniças que empestavam o caminho. As palavras de sinhá Vitoria encantavamno. Iriam para diante, alcançariam uma terra desconhecida. Fabiano estava contente e acreditava nessa terra, porque não sabia como ela era nem onde era. Repetia docilmente as palavras de sinhá Vitoria, as palavras que sinhá Vitoria murmurava porque tinha confiança nele. E andavam para o sul, metidos naquele sonho. Uma cidade grande, cheia de pessoas fortes. Os meninos em escolas, aprendendo coisas difíceis e necessárias. Eles dois velhinhos, acabando-se como uns cachorros, inúteis, acabando-se como Baleia. Que iriam fazer? Retardaram-se, temerosos. Chegariam a uma terra desconhecida e civilizada, ficariam presos nela. E o sertão continuaria a mandar gente para lá. $O$ sertão mandaria para a cidade homens fortes, brutos, como Fabiano, sinhá Vitoria e os dois meninos.

Há na narrativa o tom de esperança pelo espectro de uma vida nova. Talvez seja esse o papel da desconstrução, nos fazer caminhar, fazer de nós eternos retirantes $^{33}$.

\footnotetext{
${ }^{32}$ SAVIAN FILHO, op. cit., p. 43.

${ }^{33}$ Poema "dois e dois: quatro", de Ferreira Gullar: "Como dois e dois são quatro/ sei que a
} 


\section{REFERÊNCIAS}

CHUEIRI, Vera Karam de. Direito e literatura. In. BARRETO, Vicente de Paulo. Dicionário de filosofia do direito. Rio de Janeiro/São Leopoldo: Renovar/Unisinos, 2006.

DERRIDA, Jacques. Force de loi: le fondement mystique de l'autorité. Desconstruction and the possibility of Justice. Cardozo Law Review, v. 11, n.5-6, july 1990.

. Adeus a Emmanuel Lévinas. São Paulo: Debates, 2004.

ESTRADA, Paulo Cesar. Às margens: a propósito de Derrida. São Paulo: Loyola, 2002.

. Desconstrução e ética: ecos de Jacques Derrida. São Paulo: Loyola, 2004.

HADDOCK-LOBO, Rafael. As muitas faces do outro em Lévinas. In: DERRIDA, Jacques. Desconstrução e ética: ecos de Jacques Derrida. São Paulo: Loyola, 2004.

KOZICKI, Katya. A interpretação do direito e a possibilidade de justiça em Jacques Derrida. In: . Crítica da modernidade: diálogos com o direito. Florianópolis: Boiteux, 2005.

LÉVINAS, Emmanuel. Entre nós: ensaios sobre a alteridade. Trad. Pergentino S. Pivatto (coord). Petrópolis: Vozes, 2005. 1997.

. Quelques réflexions sur la philosophie du l'hitlérisme. Paris: Payot \& Rivages,

ㄱ. Transcendência e inteligibilidade. Trad. José F. Colaço. Lisboa: Edições 70, 1991.

. Totalité et infini: essai sur l'exteriorité. Paris: Kluver Academic, 1981.

Quatre lectures talmudiques. Paris: Minuit, 1968.

Liberté et commandement. In: ; PEPERZAK, A. Ética prima come filosofia. Milão: Guerini e Associados, 1993. (O ensaio Liberté et commandement foi publicado originalmente na Revue de métaphysique et morale, LVIII, 1953, p. 264272, tradução italiana Libertà e comando)

LOBO, R. H. As muitas faces do outro em Lévinas. In: DERRIDA, Jacques.

vida vale a pena/ embora o pão seja caro/ e a liberdade pequena." Disponível em: $<$ http://portalliteral.terra.com.br/ferreira_gullar/index.htm>. Acesso em: 10 set. 2007. 
Desconstrução e ética: ecos de Jacques Derrida. São Paulo: Loyola, 2004.

MOISÉS, Leyla Perrone. Desconstruindo estudos culturais. Disponível em: $<$ http://www.ufscar.br > Acesso em: 14 jul. 2006.

MOISÉS, Leyla Perrone. Entre o perigo e a chance. Revista Cult, São Paulo, a. 10, v. 117, p. 46, set. 2007.

MOUFFE, Chantal. Desconstruction, pragmatism and the politics of democracy. In: Desconstruction and pragmatism. London: Routledge, 1997.

NASCIMENTO, Evandro (org). Jacques Derrida: pensar a desconstrução. São Paulo: Estação Liberdade, 2005.

OST, François. Contar a lei: as fontes do imaginário jurídico. São Leopoldo: Unisinos, 2004.

RAMOS, Graciliano. Vidas secas. Rio de Janeiro: Record, 2005.

ROLANDO, Rossana. Emmanuel Levinas: para uma sociedade sem tiranias. Disponível em: <http://www.scielo.br > Acesso em: 14 set. 2006.

SAVIAN FILHO, Juvenal. Derrida e a defesa da honra da razão. Revista Cult, São Paulo, a. 10, v. 117, p. 43, set. 2007. 